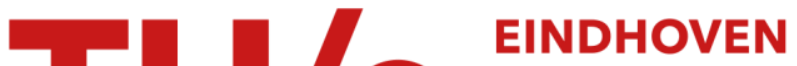 UNIVERSITY OF TECHNOLOGY
}

\section{Mass transfer at a rotating ring-cone electrode and its use to determine supersaturation of gas evolved}

Citation for published version (APA):

Janssen, L. J. J., \& Barendrecht, E. (1984). Mass transfer at a rotating ring-cone electrode and its use to determine supersaturation of gas evolved. Electrochimica Acta, 29(9), 1207-1212. https://doi.org/10.1016/00134686(84)87180-7

DOI:

10.1016/0013-4686(84)87180-7

Document status and date:

Published: 01/01/1984

\section{Document Version:}

Publisher's PDF, also known as Version of Record (includes final page, issue and volume numbers)

\section{Please check the document version of this publication:}

- A submitted manuscript is the version of the article upon submission and before peer-review. There can be important differences between the submitted version and the official published version of record. People interested in the research are advised to contact the author for the final version of the publication, or visit the $\mathrm{DOI}$ to the publisher's website.

- The final author version and the galley proof are versions of the publication after peer review.

- The final published version features the final layout of the paper including the volume, issue and page numbers.

Link to publication

\section{General rights}

Copyright and moral rights for the publications made accessible in the public portal are retained by the authors and/or other copyright owners and it is a condition of accessing publications that users recognise and abide by the legal requirements associated with these rights.

- Users may download and print one copy of any publication from the public portal for the purpose of private study or research.

- You may not further distribute the material or use it for any profit-making activity or commercial gain

- You may freely distribute the URL identifying the publication in the public portal.

If the publication is distributed under the terms of Article 25fa of the Dutch Copyright Act, indicated by the "Taverne" license above, please follow below link for the End User Agreement:

www.tue.nl/taverne

Take down policy

If you believe that this document breaches copyright please contact us at:

openaccess@tue.nl

providing details and we will investigate your claim. 


\title{
MASS TRANSFER AT A ROTATING RING-CONE ELECTRODE AND ITS USE TO DETERMINE SUPERSATURATION OF GAS EVOLVED
}

\author{
L. J. J. JANSSEN and E. BARENDRECH'I
}

\begin{abstract}
Laboratory for Electrochemistry, Department of Chemical Technology, Eindhoven University of Technology, P. O. Box 513, 5600 MD Iindhoven, The Netherlands
\end{abstract}

(Received 6 December 1983; in revised form 9 February 1984)

\begin{abstract}
The rotating ring-cone electrode ( $r$ rce) is a useful electrode assembly to study electrochemical reactions, in particular, when gas bubble formation occurs. The aim of this study is to characterize the rate of mass transfer from the bulk to the cone of a rrce, to determine its collection efficiency, $N$, in the prescnce or absence of gas bubble formation, and to investigate its usefulness for determination of the oxygen supersaturation at an oxygen-evolving electrode. The mass transfer coefficient for the cone of a rrce increases linearly with increasing rate of oxygen evolution, while $N$ declines sharply with increasing rate of oxygen evolution on the cone. In the absence of gas bubble formation $N$ is determined by the rrce geometry factors except the cone angle. The rrce can be used successfuliy to determine the supersaturation concentration of oxygen on an oxygen-evolving electrode. The absorption of dissolved oxygen by bubbles during the transport of supersaturated solution from the cone to the ring will be, however, a rather complicating factor.
\end{abstract}

\section{NOMENCLATURE}

A surface area of working electrode

c concentration

$c^{*} \quad$ concentration in bulk of electrolyte

$c^{0}$ concentration on electrode surface

$c_{s}$ saturation concentration of oxygen at a pressure of $1 \mathrm{~atm}$

$\Delta c$ supersaturation of dissolved oxygen on cone of rrce

$\Delta c_{1} \quad \Delta c$ when the absorption is dissolved oxygen by bubbles during the transport of solution is neglected

$\Delta c_{2}$ decrease of $\Delta c$ by absorption of dissolved oxygen by bubbles during the transport of solution

$D$ diffusion coefficient

E electrode potential vs sce

$F \quad$ Faraday constant

$i$ current density

$I$ current

$I^{*}$ current due to bulk concentration

$I^{* 0} \quad I^{0}$ at $I_{C}=0 \mathrm{~mA}$

$I_{x} \quad I$ for oxidation or reduction of species $x$

$\Delta I$ current due to supersaturation of solution at cone of rrce

$k_{\mathrm{x}} \quad$ mass transfer coefficient of species $x$

$n_{x}$ number of electrons involved in oxidation or reduction of 1 molecule $x$

$N$ collection efficiency of rrce

$N_{0} \quad N$ in absence of gas bubble formation

$r_{C}$ radius of the base of cone of rrce

Sc Schmidt number

v kinematic liquid viscosity

$\theta$ cone angle of rrce

$\omega$ rotation speed of rree

Subscripts

b supporting electrolyte

C cone of rrce

1 limiting conditions

$R$ ring of rrce

p peak conditions

\section{INTRODUCTION}

A rotating cone electrode, rce, can be used successfully for electrochemical characterization, just as a rotating disc electrode, in particular when gas evolution occurs[1]. It is likely that a rotating ring-cone electrode offers similar possibilities for research as a rotating ring-disc electrode. Moreover, a rotating ring-cone electrode (rrce) has additional advantages during gas evolution.

Kirowa-Eisner and Gileadi[1] have found that the limiting current at a rolating cone electrode behaves according to a theoretical equation.

The first aim of this study is to characterize the rate of mass transfer to cone and ring and to find an expression for the collection efficiency $N$ of a rrce when, whether or not, gas evolution on the cone occurs. It is well known that the solution at the surface of a gas-evolving electrode is supersaturated with the gas evolved. In a survey by Vogt[2] about supersaturation of the solution in the vicinity of gas-evolving electrodes, he stated that the experimental results varied considerably, even to a factor of 100 .

The second aim of this study is, therefore, to investigate whether a rrce is useful to determine oxygen supersaturation of solution at the surface of an oxygen-evolving electrode.

\section{EXPERIMENTAL}

An ordinary electrolysis cell with working and counter electrode compartment, both about $100 \mathrm{~cm}^{3}$, is used. A cation exchange membrane is used to separate both compartments. 
The experiments were carried out with a $\mathbf{P t}$ ring-Pt cone electrode, represented in Fig. 1. The cone used is a right cone. The radius of its base is $2.73 \mathrm{~mm}$ and the area of its curved surface is $16.55 \mathrm{~mm}^{2}$. The ring is frustum of the right cone; the radius of its base is $3.34 \mathrm{~mm}$ and of its top $2.99 \mathrm{~mm}$. The exposed area of the curved surface of the ring is $4.92 \mathrm{~mm}^{2}$. The thickness of the electrically insulating Kel-F layer is $0.18 \mathrm{~mm}$. A flat platinum electrode of about $5 \mathrm{~cm}^{2}$ served as the counter electrode and a saturated calomel electrode (sce) as the reference electrode, to which all potentials are referred. All experiments were carried out in a $1 \mathrm{M} \mathrm{KOH}$ solution, containing either a small quantity of $\mathrm{K}_{3} \mathrm{Fe}(\mathrm{CN})_{6}$ or $\mathrm{K}_{4} \mathrm{Fe}(\mathrm{CN})_{6}$, or none of both. The electrolysis cell is kept at $298 \mathrm{~K}$. The rrce is rotated by a rotator (Motomatic, model E-550-M). To determine the mass transfer to both cone and ring of the rrce, its collection efficiency $N$ and the supersaturation concentration, potential-current measurements were performed with a bipotentiostat (Tacussel, type BI-PAD) and a voltage scan generator (Wenking, model VSG 72). The potential-current curves were recorded with an $X-Y$ recorder (Philips PM 8041). Unless otherwise stated, the scan rate is $10 \mathrm{mV} \mathrm{s}^{-1}$. The rate of mass transfer of $\mathrm{Fe}(\mathrm{CN})_{6}^{4-}$ to the oxygenevolving cone in a solution containing $0.04 \mathrm{M}$ $\mathrm{K}_{4} \mathrm{Fe}(\mathrm{CN})_{6}$ was obtained by iodometric determination of the quantity of $\mathrm{Fe}(\mathrm{CN})_{6}^{3-}$ formed in a fixed period of electrolysis time[3].

\section{RESULTS}

3.1. Mass transfer to, and collection efficiency, $N_{0}$, of the rrce in the absence of gas evolution at the cone

The limiting rate of mass transfer of $\mathrm{Fe}(\mathrm{CN})_{6}^{3-}$ ions to either the cone or the ring was determined as a function of the rotation speed for a $1 \mathrm{M} \mathrm{KOH}$ solution containing various concentrations of $\mathrm{K}_{3} \mathrm{Fe}(\mathrm{CN})_{6}$. It has been found that for both the cone and the ring electrode the limiting current for the reduction of $\mathrm{Fe}(\mathrm{CN})_{6}^{3-}$-ions is proportional to the square root of the rotation speed. The experimental slope of $\mathrm{d} I_{\mathrm{C}, \mathrm{l}, \mathrm{Fe}(\mathrm{III} / \mathrm{d}} / \mathrm{d} \omega$ is $0.255 \times 10^{-3} \mathrm{~A} \mathrm{rad}^{-1 / 2} \mathrm{~s}^{1 / 2}$ for a $0.04 \mathrm{M} \mathrm{K}_{3} \mathrm{Fe}(\mathrm{CN})_{6}$ in a $1 \mathrm{M} \mathrm{KOH}$ solution at $298 \mathrm{~K}$. Here. $I_{\mathrm{Cl}, \mathrm{Fe}(\mathrm{III})}$ is the limiting cone current. This value of slope is compared with the one calculated according to[1]:

$\frac{\mathrm{d} I_{\mathrm{C}, \mathrm{LFe}(\mathrm{III})}}{\mathrm{d} \sqrt{ } \omega}=n_{\mathrm{Fe}(\mathrm{III})} F c^{*}{ }_{\mathrm{Fe}(\mathrm{III})} r_{\mathrm{C}}^{2} \nu^{1 / 2} S c^{-2 / 3} \sin ^{1 / 2} \theta$.

Substituting $n_{\mathrm{Fe}(\mathrm{III})}=1$ electrons $/$ molecule $\mathrm{Fe}(\mathrm{CN})_{6}^{3-}$, $F=96500 \mathrm{C} \mathrm{mol}^{-1}, \quad c_{F_{\mathrm{e}}(\mathrm{III})}=4 \times 10^{-5} \mathrm{~mol} \mathrm{~cm}^{-3}$ $r_{\mathrm{C}}=0.273 \mathrm{~cm}, v$ for $1 \mathrm{M} \mathrm{KOH}$ at $298 \mathrm{~K}$ $=0.01073 \mathrm{~cm}^{2} \mathrm{~s}^{-1}, \quad S c=1358$ with $D_{\mathrm{Fe}(\mathrm{HI})}=0.79$ $\times 10^{-5} \mathrm{~cm}^{2} \mathrm{~s}^{-1}[3]$ and $\sin \theta=0.7071$, into Equation (1) gives a slope of $0.28 \times 10^{-3} \mathrm{~A} \mathrm{rad}^{-1 / 2} \mathrm{~s}^{1 / 2}$. The agreement between theory and experiment is good if

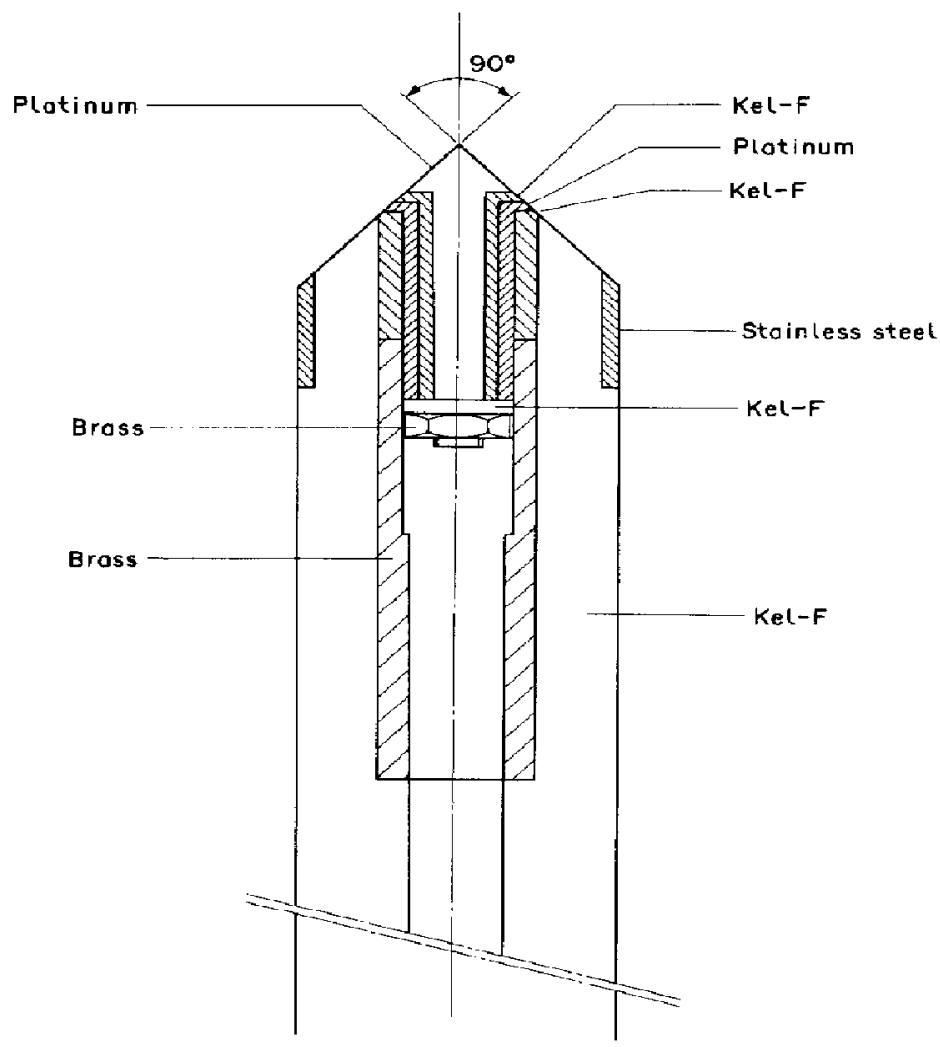

Fig. 1. Diagram of a ring-cone electrode. 
taking into account the inaccuracy in some parameters like the radius $r_{C}$.

The collection efficiency $N_{0}$ of the rrce was determined for various rotation speeds and for a $1 \mathrm{M}$ $\mathrm{KOH}+0.04 \mathrm{M} \mathrm{K} \mathrm{K}_{3} \mathrm{Fe}(\mathrm{CN})_{6}$ solution at $298 \mathrm{~K}$. The limiting current for the oxidation of $\mathrm{Fe}(\mathrm{CN})_{6}^{4-}$-ions on the ring, $I_{R, 1, \text { Fe(II), }}$ is plotted $v s$ the current for reduction of Fe(CN) ${ }_{6}^{3-}$-ions on the cone, $I_{\text {C,Fe(III) }}$ in Fig. 2. This figure shows that $I_{R, I, F e(I)}$ has the same proportionality factor to $I_{C, F e(I I I)}$ for rotation speeds of 10,20 and $40 \mathrm{revs}^{-1}$ ie the collection efficiency, $N_{0}$ $=I_{R, 1, F e(I I)} / I_{C_{\text {G }} \text { Fe(III) }}$ (here $=0.25$ ) does not depend on the rotation speed.

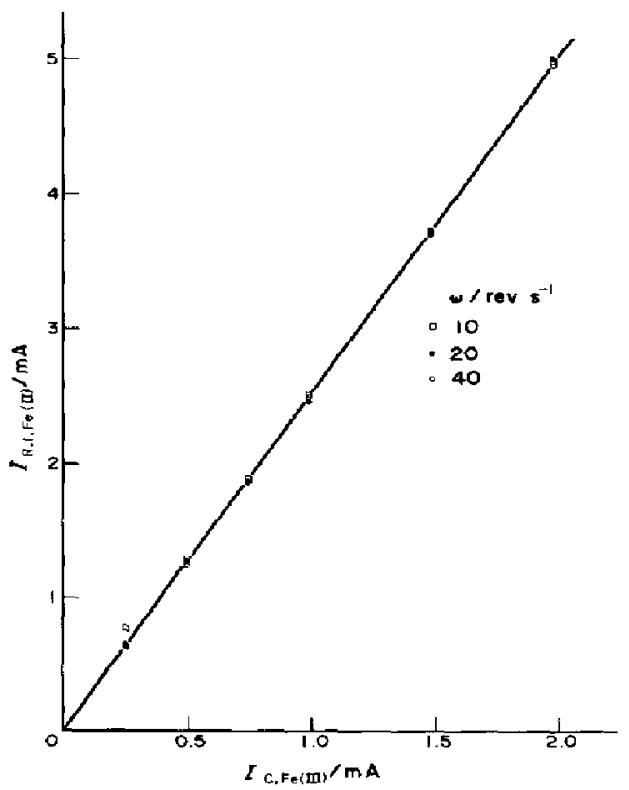

Fig. 2. Limiting ring current for oxidation of $\mathrm{Fe}(\mathrm{CN})_{6}^{4}$ formed at the cone plotted bs the the cone current for reduction of $\mathrm{Fe}(\mathrm{CN})_{6}^{3-}$ for a rrce in a $1 \mathrm{M} \mathrm{KOH}+0.04 \mathrm{M}$ $\mathrm{K}_{3} \mathrm{Fe}(\mathrm{CN})_{6}$ at $298 \mathrm{~K}$ and various rotation speeds of rrce. During the measurement the potential of the ring is swept from 0.27 to $0.56 \mathrm{~V}$ with a scan rate of $20 \mathrm{mV} \mathrm{s}^{-1}$.

As known, the collection efficiency for a rotating ring-disc electrode (rrde) is characterized by three radii, viz the radius of disc electrode, and the inner and outer radius of the ring electrode[4], and is tabulated for different ratios of these radii[ 5 ]. Using table 8.1 of [5] and the radii for the cone base, the base and the top of the frustum of the cone (ring), it can. be calculated that $N_{0}=0.24$, ie close to the experimental value. Consequently, it is likely that $N_{0}$ for a rrce is characterized by similar factors as $N_{0}$ for a rrde.

3.2. Mass transfer to, and collection efficiency, $\mathrm{N}$, of Irce at gas evolucion on the cone

To investigate the mass transfer to, and the collection efficiency, $N$, of the rrce at oxygen evolution on the cone, experiments were carried out in a $1 \mathrm{M} \mathrm{KOH}$ $+0.04 \mathrm{M} \mathrm{K} \mathrm{K}_{4} \mathrm{Fe}(\mathrm{CN})_{6}$ solution at $298 \mathrm{~K}$. During oxygen evolution on a platinum cone electrode in a $1 \mathrm{M} \mathrm{KOH}$ solution containing small quantities of $\mathrm{Fe}(\mathrm{CN})_{6}^{4-}-$-ions, the concentration of $\mathrm{Fe}(\mathrm{CN})_{6}^{4-}$-ions at its surface is almost zero[3]. A fraction of the electric current on the cone is used for oxidizing $\mathrm{Fe}(\mathrm{CN})_{6}^{4-}$ ions to $\mathrm{Fe}(\mathrm{CN})_{6}^{3-}$-ions, the other part for oxygen evolution. Consequently, $I_{\mathrm{C}}=I_{\mathrm{C}_{\mathrm{H}} \mathrm{O}}+I_{\mathrm{C}, \mathrm{l}, \mathrm{Fe}(\mathrm{II})}$. The mass transfer coefficient is defined as

$$
k_{\mathrm{C}, \mathrm{Fe}(\mathrm{II})}=I_{\mathrm{C}, \mathrm{l}, \mathrm{Fe}(\mathrm{II})} / n_{\mathrm{Fe}(\mathrm{II})} F A_{\mathrm{C}} \mathcal{C}_{\mathrm{Fe}(\mathrm{II})}^{*}
$$

The current $I_{\mathrm{Cl}, \mathrm{Fe}(\mathrm{II})}$ was obtained from the quantity of Fe(CN) ${ }_{6}^{3-}$-ions formed during a $20 \mathrm{~min}$ electrolysis.

In Fig. $3 k_{\mathrm{C}_{3} \text { Fefly }}$ is plotted os $i_{\mathrm{CH}_{2} \mathrm{O}}$ for a rotation speed of $10 \mathrm{revs}^{-1}$ and in Fig. $4 k_{\mathrm{C}, \mathrm{Fe}(\mathrm{II})} v \mathrm{v}$ the square root of the rotation speed at $i_{C}=0.60 \mathrm{kA} \mathrm{m}^{-2}$ for a $1 \mathrm{M} \mathrm{KOH}+0.04 \mathrm{M} \mathrm{K} \mathrm{Fe}_{4}(\mathrm{CN})_{6}$ solution at $298 \mathrm{~K}$. For the experiments of Fig. 4 at a constant $i_{C}$ value, viz $0.60 \mathrm{kA} \mathrm{m}^{-2}$, the relative decline of $i_{C, O_{2}}$ at increasing $\omega$, is small at $\omega<8$ revs $^{-1}$ and rather high at

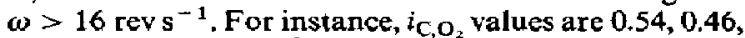
0.36 and $0.20 \mathrm{kA} \mathrm{m}^{-2}$ at, respectively, $\omega$ values of 2,8 , 16 and 64 revs $^{-1}$.

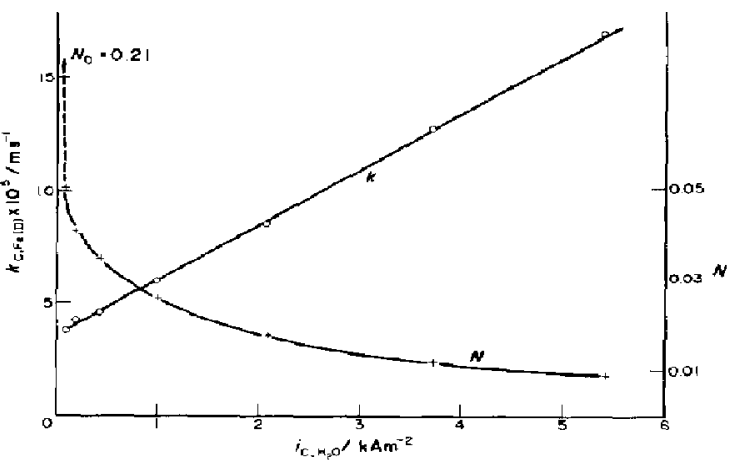

Fig. 3. The mass transfer coefficient for $F(C N)_{6}^{4-}$ to the cone and the collection efficiency $N$ for a rrce are plotted $v s$ the current density of oxygen evolution on the cone. The experiments were carrjed out in a $1 \mathrm{M} \mathrm{KOH}+0.04 \mathrm{M}$ $\mathrm{K}_{4} \mathrm{Fe}(\mathrm{CN})_{6}$ solution at $298 \mathrm{~K}$; the rotation speed of the rrce was 10 rev s$^{-1}$ and the potential scan rate $10 \mathrm{mV} \mathrm{s}^{-1}$.

In the beginning of the $20 \mathrm{~min}$ cone electrolysis current-potential curves at both decreasing and increasing ring potentials between 0.5 and $-0.7 \mathrm{~V}$ were recorded. The current $I_{R, \text {, Fe(III) }}$ was obtained from the curve at decreasing potential. (The limiting current, found from the curve at increasing potential is slightly lower, probably due to electrode poisoning.) In Fig. 3, also the collection efficiency $N$, is plotted $v s i_{\mathrm{C}_{2} \mathrm{H}_{2} \mathrm{O}}$ at $\omega=10 \mathrm{revs}^{-1}$ and so in Fig. 4 vs $\omega$ at $i_{\mathrm{C}}=0.60 \mathrm{kA} \mathrm{m}^{-2}$.

From Fig. 3 it follows that $N$ declines strongly and $k_{\mathrm{C}, \mathrm{Fe}(\mathrm{II})}$ increases almost linearly with increasing $i_{\mathrm{C}, \mathrm{O}_{2}}$. Figure 4 shows an almost linear increase of $k_{\mathrm{C}, \mathrm{Fe}(\mathrm{II})}$ at increasing $\sqrt{ } \omega$ and the $N / \omega^{1 / 2}$ curve has a clear minimum. This can be explained by three factors opposing each other, viz the increase of $\omega$ diminishes $N$, the decline of $i_{\mathrm{CO}}$, at increasing $\omega$ enhances $N$, and by a change of behaviour of oxygen bubbles at increasing $\omega$. 


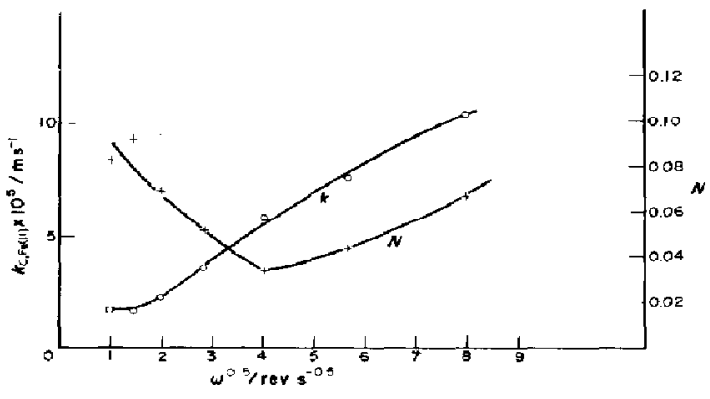

Fig. 4. The mass transfer coefficient for $\mathrm{Fe}(\mathrm{CN})_{6}^{4-}$ to the cone and the collection efficiency $N$ for a rrce are plotted $v$ the square root of the rotation speed at a cone current density of $0.60 \mathrm{kA} \mathrm{m}^{-1}$. The experiments were carried out in a $1 \mathrm{M}$ $\mathrm{KOH}+0.04 \mathrm{M} \mathrm{K}_{4} \mathrm{Fe}(\mathrm{CN})_{6}$ solution at $298 \mathrm{~K}$; the potential scan rate was $10 \mathrm{mVs}^{-1}$.

\subsection{Supersaturation of oxygen}

The concentration of oxygen at the surface of an oxygen evolving electrode, $c_{\mathbf{O}_{2}}^{\mathbf{b}}$, in a solution saturated with oxygen is higher than the concentration of oxygen in the bulk of the electrolyte, $c_{0}^{*}$. The latter is the saturation concentration, $c_{s}$, at a pressure of 1 atm. The supersaturation concentration of dissolved oxygen on the cone electrode is $\Delta c=c_{\mathrm{o}}^{0},-c_{\mathrm{s}}$.

As for a rrde, the collection efficiency, $N_{0}$, for a rrce does not depend on the nature of non-volatile compounds. If the bulk concentration of oxygen is not zero, there will be a finite limiting ring current at $I_{C}$ $=0$. Moreover, the mass transfer coefficient, $k_{\mathrm{C}_{2} \mathrm{O}_{2}}$ for oxygen from the bulk of solution to the ring will depend on the rate of volumetric oxygen bubble evolution on the cone. To determine the ring current due to the saturation concentration of oxygen, $\mathrm{K}_{3} \mathrm{Fe}(\mathrm{CN})_{6}$ was added to the supporting electrolyte.

In Fig. 5 characteristic $E_{R}$ vs $I_{R}$ curves at various $I_{C}$ are shown for a rrce in a $1 \mathrm{M} \mathrm{KOH}+0.004 \mathrm{M}$ $\mathrm{K}_{3} \mathrm{Fe}(\mathrm{CN})_{6}$ solution saturated at $1 \mathrm{~atm}$ with oxygen. The cathodic voltammograms at $-0.1 \mathrm{~V}<E<0.3 \mathrm{~V}$ have a wave with a reasonable constant level for the reduction of $\mathrm{Fe}(\mathrm{CN})_{6}^{3-}$-ions, and at $E<-0.1 \mathrm{~V}$ have a wave with a small peak at about $E=-0.45 \mathrm{~V}$ for reduction of oxygen.

At a rotation speed of $10 \mathrm{revs}^{-1}$ and at $I_{C}=0 \mathrm{~mA}$, the limiting current $I_{R, l, \text { re(III) }}$ increases only to a small extent with increasing potential scan rate. The peak current for the reduction of oxygen increases, however, strongly with increasing potential scan rate and ap-

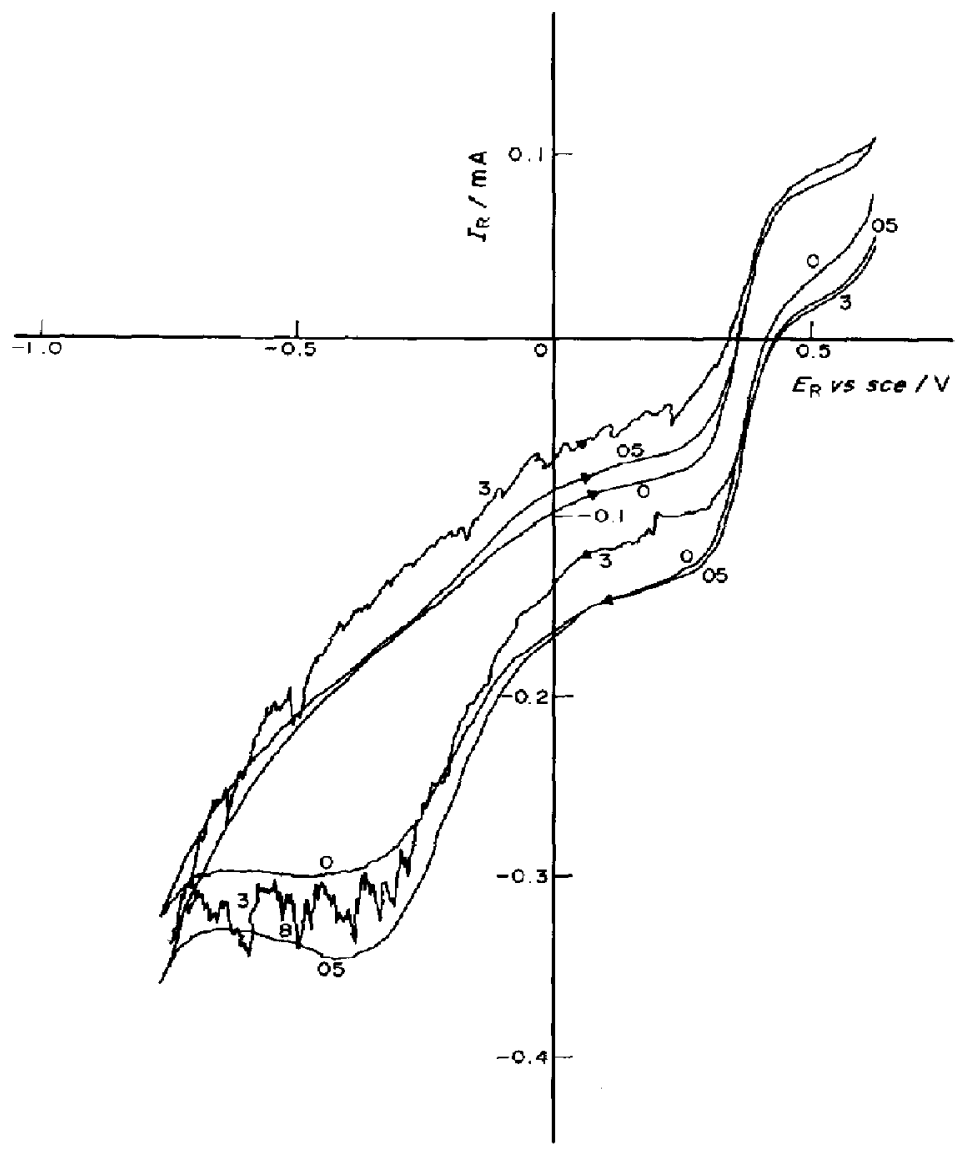

Fig. 5. Voltammograms for the ring of a rrce in a $1.0 \mathrm{M} \mathrm{KOH}+0.004 \mathrm{M} \mathrm{K}_{3} \mathrm{Fe}(\mathrm{CN})_{6}$ solution saturated with oxygen and at various anodic cone currents, $298 \mathrm{~K}$, scan rate of $10 \mathrm{mV} \mathrm{s}^{-1}$. 
proaches a constant value at a potential scan rate of about $30 \mathrm{mVs}^{-1}$. At high potential scan rates the voltammogram for the supporting electrolyte (1 M $\mathrm{KOH}$ ) interferes with the voltammograms for oxygen and $\mathrm{Fe}(\mathrm{CN})_{6}^{3-}$ reduction.

Weighing out these effects - ie decrease of oxygen peak current at decreasing scan rate and increase of the effect of supporting electrolyte and of oxides present on platinum electrodes at increasing scan rate-in order to determine the supersaturation of oxygen at the gas evolving cone electrode, the experiments were carried out at a potential scan rate of $10 \mathrm{mVs}^{-1}$. Assuming proportionality between peak and limiting current for the reduction of oxygen, then $I_{\mathrm{R}, \mathrm{p} . \mathrm{O}_{2}}$ $=a I_{\mathrm{R}, 1, \mathrm{O}_{2}}$. From the relation for the rate of mass Iransfer at forced convection [7] and from $n_{\mathrm{p}, \mathrm{O}_{2}}=a n_{\mathrm{O}_{2}}$ where $n_{\mathrm{p}, \mathrm{O}}$, is the number of electrons involved in the reduction of 1 molecule $\mathrm{O}_{2}$ transferred by diffusion, it follows that for $I_{\mathrm{C}}=0 \mathrm{~mA}$

$$
\frac{n_{\mathrm{p}, \mathrm{O}_{2}}}{n_{\mathrm{Fe}(\mathrm{III})}}=\frac{I_{\mathrm{R}, \mathrm{p}, \mathrm{O}_{2}}^{* \mathrm{O}}}{I_{\mathrm{R}, \mathrm{l}_{2} \mathrm{Fe}(\mathrm{III})}^{* \mathrm{~N}}}\left(\frac{D_{\mathrm{Fe}(\mathrm{HII})}}{D_{\mathrm{O}_{2}}}\right)^{2 / 3} \frac{c_{\mathrm{Fe}(\mathrm{II})}}{c_{\mathrm{s}}}
$$

where $I_{R}^{*}$ is the ring current due to bulk concentration and $I_{\mathrm{R}}^{*}$ is $I_{\mathrm{R}}^{*}$ at $I_{\mathrm{C}}=0 \mathrm{~mA}$.

To determine $n_{\mathrm{p}, \mathrm{O}}$, the oxygen peak ring current $I_{\mathrm{R}, \mathrm{p}, \mathrm{O}_{z}}^{\mathrm{O}}$ was obtained from experiments with an oxygenfree and an oxygen-saturated solution of $1 \mathrm{M} \mathrm{KOH}$ $+0.004 \mathrm{M} \mathrm{K}_{3} \mathrm{Fe}(\mathrm{CN})_{6}$. The oxygen peak ring current occurs at about $-0.5 \mathrm{~V}$. It has been found that for the oxygen-free solution the ring current $I_{R, b}$ at $-0.5 \mathrm{~V}$ is relatively small, viz $0.025 \mathrm{~mA}$ being about $15 \%$ of $I_{\mathrm{R}, \mathrm{p}, \mathrm{O}_{2}}^{* 0}$. Consequently, $I_{\mathrm{R}, \mathrm{p}, \mathrm{O}_{2}}^{* 0}=I_{\mathrm{R}, \mathrm{p}}-0.025 \mathrm{~mA}$ where $I_{\mathrm{R}, \mathrm{p}}$ is the peak ring current at the potential of the oxygen peak, viz $-0.5 \mathrm{~V}$.

A number $n_{\mathrm{p}, \mathrm{O}}=3.0$ is calculated by introducing in Equation (2): $I_{\mathrm{R}, \mathrm{P}, \mathrm{O}_{2}}^{*}$ at $I_{\mathrm{C}}=0 \mathrm{~mA}, I_{\mathrm{R}, \mathrm{l}, \mathrm{Fe}(\mathrm{II})}^{*}$ at $I_{\mathrm{C}}$ $=0 \mathrm{~mA}$, the saturation concentration of oxygen in $1 \mathrm{M} \mathrm{KOH}$, viz $0.89 \mathrm{mM}[6], c_{\mathrm{Fe}(\mathrm{III}) \text {, the diffusion }}$ coefficient of $\mathrm{Fe}(\mathrm{CN})_{6}^{3-}$, viz $0.79 \times 10^{-9} \mathrm{~m}^{2} \mathrm{~s}^{-1}[3]$, the diffusion coefficient of dissolved oxygen, viz 1.59 $\times 10^{-9} \mathrm{~m}^{2} \mathrm{~s}^{-1}[6]$, and $n_{\mathrm{Fe}(\mathrm{III})}=1$ electron per molecule $\mathrm{Fe}(\mathrm{CN})_{6}^{3-}$ and $n_{\mathrm{O}_{2}}=4$ electrons per molecule $\mathrm{O}_{2}$.

Evolution of oxygen bubbles on the cone causes an additional flow of solution in the neighbourhood of the ring and will affect in the same degree the transfer of all dissolved species from the bulk of solution to the ring. Consequently,

$$
I_{\mathbf{R}, \mathrm{P}, \mathrm{O}_{2}}^{*}=I_{\mathbf{R}, 1, \mathrm{Fe}(\mathrm{III})}^{*} I_{\mathbf{R}, \mathrm{p}, \mathrm{O}_{2}}^{* 0} / I_{\mathrm{R}, 1, \mathrm{Fe}(\mathbf{I I I})}^{* 0}
$$

The peak ring current for oxygen reduction due to supersaturation of the solution at the cone, is given by $\Delta I_{\mathrm{R}_{1}, \mathrm{O}_{3}}=I_{\mathrm{R}, \mathrm{P}, \mathrm{O}_{2}}-I_{\mathrm{R}, \mathrm{p}, \mathrm{O}_{3}}^{*}$. From $\Delta I_{\mathrm{R}, \mathrm{p}, \mathrm{O}_{2}}$ and the collection efficiency $N$ and taking into account a difference between the number of electrons for the reduction of oxygen at the ring and the one for the formation of oxygen at the cone, it follows that the cone current used for the supersaturation of the solution at the cone is given by

$$
\Delta I_{\mathrm{C}, \mathrm{H}_{2} \mathrm{O}}=\frac{\Delta I_{\mathrm{R}, \mathrm{p}, \mathrm{O}_{2}}}{N} \frac{n_{\mathrm{O}_{2}}}{n_{\mathrm{p}, \mathrm{O}_{2}}}
$$

If the concentration profile at the cone for dissolved oxygen is similar to that for $\mathrm{Fe}(\mathrm{CN})_{6}^{3-}$ formed by oxidation of Fe(CN) ${ }_{6}^{4-}$ during oxygen evolution, the relation between $\Delta I_{C_{H_{2}} \mathrm{O}}$ and the oxygen supersaturation at the cone, $\Delta C_{1}$ is given by

$$
\Delta I_{{\mathrm{C}, \mathrm{H}_{2} \mathrm{O}}}=n_{\mathrm{O}_{2}} F k_{{\mathrm{C}, \mathrm{O}_{2}}_{2}} A_{\mathrm{C}} \Delta c_{1} \text {. }
$$

Substitution of this relation for $\Delta I_{\mathrm{C}_{, \mathrm{H}_{2} \mathrm{O}} \mathrm{O}}$ into Equation (3) gives

$$
\Delta c_{1}=\Delta I_{\mathrm{R}, \mathrm{p}, \mathrm{O}_{2}} / n_{\mathrm{p}, \mathrm{O}_{2}} F N k_{\mathrm{C}_{,} \mathrm{O}_{2}} A_{\mathrm{C}}
$$

Next, it is assumed that during the transport of supersaturated solution and oxygen bubbles from the cone to the ring electrode dissolved oxygen is not taken up by the bubbles transported.

The supersaturation concentration of oxygen at the gas evolving cone electrode has been calculated with the experimental results of $\Delta I_{R, p, O_{2}, N}$ (Fig. 3),

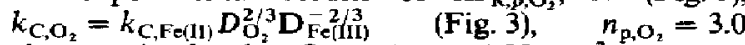
electrons/molecule $O_{2}, A_{C}=16.55 \mathrm{~mm}^{2}$ and $F$ $=96500 \mathrm{Cmol}^{-1}$. The results are given in Fig. 6 as a function of $i_{\mathrm{C}, \mathrm{H}_{2}} \mathrm{O}$.

At very high current densities, viz $i_{\mathrm{C}, \mathrm{H}_{2} \mathrm{O}}$ $>4 \mathrm{kA} \mathrm{m}^{-2}, \Delta c_{1}$ was practically zero.

At a rotation speed of 10 revs $^{-1}$ and at $i_{C, H_{2} O}$ $<0.5 \mathrm{~mA}$, practically no oxygen bubbles could be observed on the cone electrode. With $k_{\mathrm{C}_{1} \mathrm{O}_{2}}=k_{\mathrm{C}, \mathrm{Fe}(\mathrm{II})}$ $D_{\mathrm{O}_{2}^{3}}^{2} / D_{\mathrm{Fe}(\mathrm{III})}^{2 / 3}$ at $i_{\mathrm{C}, \mathrm{H}_{2} \mathrm{O}}=0 \mathrm{kA} \mathrm{m}^{-2}$ (Fig. 3) it was calculated that $\Delta c=1.7 \mathrm{mM}$ at $i_{\mathrm{C}, \mathrm{H}_{2} \mathrm{O}}=0.03 \mathrm{kA} \mathrm{m}^{-2}$ From Fig. 6 it follows that $\Delta c_{1}=1.9 \mathrm{mM}$ being in reasonable agreement with the former method.

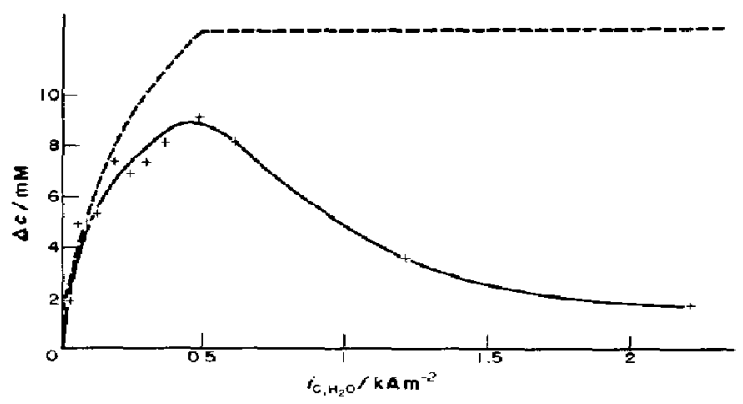

Fig. 6. Supersaturation conoentration of oxygen neglecting the absorption of dissolved oxygen by bubbles during the transport of the supersaturated solution containing oxygen bubbles (solid line) and the supersaturation concentration of oxygen obtained by the first step of the approach process (dotted line) are given as a function of cone current density of oxygen evolution for a rree in a $1 \mathrm{M} \mathrm{KOH}+0.004 \mathrm{M}$ $\mathrm{K}_{3} \mathrm{Fe}(\mathrm{CN})_{6}$ solution saturated with oxygen and at $298 \mathrm{~K}$.

\section{DISCUSSION}

\subsection{Characterization of the rrce}

In absence of gas evolution our experimental results for the mass transfer of indicator ions from the bulk of solution to the rotating cone electrode behaves according to the theoretical equations given by KirowaEisner and Gileadi[1].

From Section 3.1 it follows that the collection efficiency $N_{0}$ for a rrce is determined by its geometrical factors except the cone angle. This conclusion is likely since for a rrce the ratios between the chord length of the cones are independent of the cone angle. Of course, theoretical verification is worth doing. 
The mass transfer coefficient for a gas-evolving rotating cone electrode is strongly affected by the rate of gas evolution (Fig. 3) and the rotation speed (Fig. 4). At $i_{\mathrm{C}_{3} \mathrm{H}_{2} \mathrm{O}}>0.1 \mathrm{kA} \mathrm{m}^{-2}$, the mass transfer coefficient increases linearly with increasing $i_{\mathrm{CH}_{2}}$ (Fig. 3). This dependence reasonably agrees with the one found for both horizontally and vertically placed electrodes $[3,8]$.

The collection efficiency $N$ for a rrce declines strongly with increasing $i_{\mathrm{C}, \mathrm{H}_{2} \mathrm{O}}$. From the results of Fig. 4 it can be shown that in the $i_{C, H, O}$ range from 0.1 to $1 \mathrm{kA} \mathrm{m}^{-2} \log N$ decreases linearly with increasing $\log i_{\mathrm{C}_{2} \mathrm{O}}$; the slope of the $\log N / \log i_{\mathrm{C}, \mathrm{H}_{2} \mathrm{O}}$ curve is -0.30 . The rotation speed strongly affects $N$ for a rrce where gas is evolved at the cone (Fig. 4). From Fig. 4, and assuming a rotation speed independent slope of the $\log N / \log i_{\mathrm{CH}_{2} \mathrm{O}}$ curve, it can be shown that $N$ decreases with increasing rotation speed up to $\omega=10 \mathrm{revs}^{-1}$ and rises above $\omega=16 \mathrm{rev} \mathrm{s}^{-1}$.

\subsection{Supersaturation by oxygen}

According to Fig. 6 the $\Delta c_{1} / i_{\mathrm{C}, \mathrm{H}} \mathrm{O}$ curve has a sharp maximum at about $i_{C, \mathrm{H}_{2} \mathrm{O}}=0.3 \mathrm{kA} \mathrm{m}^{-2}$. At $i_{\mathrm{C}_{1} \mathrm{H}_{2} \mathrm{O}}$ above $0.3 \mathrm{kA} \mathrm{m}^{-2}, \Delta c_{1}$ strongly declines and approaches practically zero at high $i_{\mathrm{C}, \mathrm{H}_{2} \mathrm{O}}$. However, it is likely that $\Delta c_{1}$ will increase continuously with increasing $i_{\mathrm{C}_{1} \mathrm{O}_{2}}$.

Several investigators $[9,10]$ have found that at moderate current densities the supersaturation on a gasevolving electrode increases with increasing rate of gas evolution and that at high current densities, for instance at $i_{\mathrm{C}_{1} \mathrm{H}_{2} \mathrm{O}}>2 \mathrm{kA} \mathrm{m}^{-2}$ for hydrogen evolution in acid solution[11], the supersaturation becomes practically constant.

The results of Fig. 6 at $i_{\mathrm{C}, \mathrm{H}_{2} \mathrm{O}}>0.3 \mathrm{kA} \mathrm{m}^{-2}$ have to be influenced by absorption of dissolved oxygen by oxygen bubbles during the transport of liquid and bubbles from the cone to the ring. At increasing $i_{C, H_{2}} \mathrm{O}$ the density of bubbles in the solution near the rree increases. The rate of absorption of dissolved oxygen by bubbles must increase because of the increasing bubble population density and so the supersaturation of the liquid must decline with increasing $i_{\mathrm{C}, \mathrm{H}_{2} \mathrm{O}}$. This means that the assumption made in Section 3.3 about the collection efficiency of dissolved oxygen is surely not true for $i_{{\mathrm{C}, \mathrm{H}_{2} \mathrm{O}}} \gg 0.3 \mathrm{kA} \mathrm{m}^{-2}$. Whether this assumption will be correct at $i_{\mathrm{C}, \mathrm{H}_{2} \mathrm{O}}<0.3 \mathrm{kA} \mathrm{m}^{-2}$, has to be discussed, at least. Evidently, the rate of absorption of dissolved oxygen by bubbles decreases with decreasing $i_{\mathrm{C}_{\mathrm{H}} \mathrm{O}} \mathrm{O}$. An estimation of this effect upon the experimental $\Delta c_{1}$, can be achieved by the following approach.

Because of oxygen absorption by bubbles, $\Delta c$ values given by the solid curve of Fig. 6 are 100 low; also at low $i_{\mathrm{C}, \mathrm{H}_{2} \mathrm{O}}$. It is assumed that the oxygen supersaturation at $i_{\mathrm{C}_{\mathrm{H}} \mathrm{O}} \gg 0.5 \mathrm{kA} \mathrm{m}^{-2}$ is constant.

To obtain the $\Delta c$ decrease, $\Delta c_{2}$, due to oxygen absorption by oxygen bubbles, we assume first that $\Delta c_{1}=9 \mathrm{mM}$ at $i_{\mathrm{C}, \mathrm{H}_{2} \mathrm{O}}>0.5 \mathrm{kA} \mathrm{m}^{-2}$, ie $\Delta c_{1}$ at $i_{\mathrm{C}_{2} \mathrm{H}_{2} \mathrm{O}}$ $=0.5 \mathrm{kA} \mathrm{m}^{-2}$. The difference between $9 \mathrm{mM}$ and $\Delta c_{1}$ of Fig. 6, being $\Delta c_{2}$, is plotted $v s i_{\mathrm{C}_{\mathrm{H}_{2} \mathrm{O}}}$ for $i_{\mathrm{C}_{\mathrm{H}} \mathrm{O}}=1.2$ and $2.4 \mathrm{kA} \mathrm{m}^{-2}$. Drawing a smooth curve through the origin and the two measuring points, $\Delta c_{2}$ at $i_{\mathrm{C}_{2} \mathrm{H}_{2} \mathrm{O}}$ $<0.5 \mathrm{kA} \mathrm{m}^{-2}$ is obtained. This $\Delta c_{2}$ is added to $\Delta c_{1}$ at $i_{C, \mathrm{H}_{2} \mathrm{O}}<0.5 \mathrm{kA} \mathrm{m}^{-2}$ and again it is assumed that $\Delta c$ is constant at $i_{\mathrm{C}_{3} \mathrm{H}_{2} \mathrm{O}}>0.5 \mathrm{kA} \mathrm{m}^{-2}$. The result of this summation is represented by the dotted line in Fig. 6. Repetition of this process gives $\Delta c_{2}$ converging to $4 \mathrm{mM}$ at $i_{\mathrm{C}, \mathrm{O}_{2}}=0.5 \mathrm{kA} \mathrm{m}^{-2}$. From the $\Delta c_{2} / i_{\mathrm{C}, \mathrm{H}_{2} \mathrm{O}}$ plot obtained after this approach process, it follows that at $i_{\mathrm{C}, \mathrm{O}_{2}}<0.5 \mathrm{kA} \mathrm{m}^{-2} \Delta c_{2}$ is proportional to $i_{\mathrm{C}_{\mathrm{H}} \mathrm{H}_{2} \mathrm{O}}$.

The supersaturation concentration of oxygen on the gas-evolving cone is given by $\Delta c=\Delta c_{1}+\Delta c_{z}$. In Fig. 7 $\log \Delta c$ as well as $\log \Delta c_{1}$ are plotted es $\log i_{\mathrm{C}_{\mathrm{H}} \mathrm{O}}$. In the $i_{\mathrm{C}, \mathrm{H}, \mathrm{O}}$ range from 0.05 to $0.5 \mathrm{kA} \mathrm{m}^{-2}$ both relations can be given by a straight line. The slope of the $\log \Delta c / \log i_{\mathrm{FF}_{2} \mathrm{O}}$ line is 0.45 .

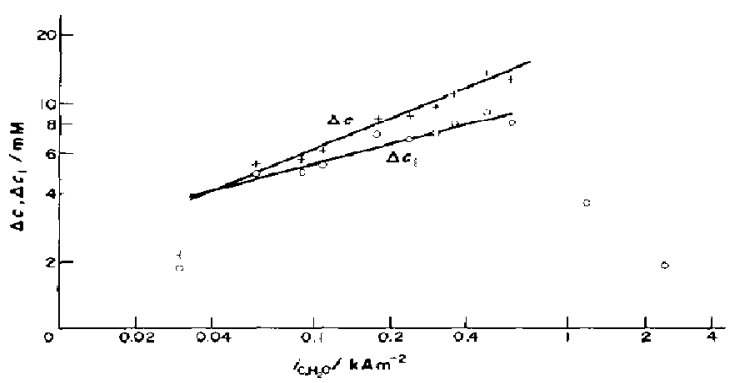

Fig. 7. Supersaturation concentration of oxygen is plotted on a double logarithmic scale vs the cone current density of oxygen evolution for a rrce in a $1 \mathrm{M} \mathrm{KOH}+0.004 \mathrm{M}$ $\mathrm{K}_{3} \mathrm{Fe}(\mathrm{CN})_{6}$ solution saturated with oxygen and at $298 \mathrm{~K}$.

For oxygen evolving electrodes in a $\mathrm{KOH}$ solution only the results of Khomskaya and Kolossov[11] are well known, but their results obtained with rrde are not usable. In acidic media Shibata[9] has determined the supersaturation concentration as a function of oxygen evolution. Plotting his results as in Fig. 7, the slope of $\log \left(\Delta c+c_{\mathrm{s}}\right) / \log i_{\mathrm{H}_{2} \mathrm{O}}$ curve at 0.05 to $1 \mathrm{kA} \mathrm{m}^{-2}$ is 0.41 . This agrees well with the one of the straight line of Fig. 7. Shibata[9] found that $\Delta c / c_{\mathrm{s}}$ at $0.5 \mathrm{kA} \mathrm{m}^{-2}$ is about 50 . From Fig. 7 and $c_{\mathrm{s}}=0.89 \mathrm{mM}$ it follows that $\Delta c / c_{s}$ at $0.5 \mathrm{kA} \mathrm{m}^{-2}$ is about 14 .

From the experimental results it can be concluded that rree can be used successfully to determine the supersaturation concentration on a gas-evolving electrode surface taking into account the effect of absorption of dissolved oxygen by bubbles during the transport of solution from the cone to the ring of the rree.

\section{REFERENCES}

1. E. Kirowa-Eisner and E. Gileadi, J. electrochem. Soc. 123, 22 (1976).

2. H. Vogt, Fortschr. Verfahrenstechnik 20, 369 (1982).

3. L. J. J. Janssen, Electrochim. Acta 23, 81 (1978)

4. W. J. Albery and M. L. Hitchman, Ring-Disc Electrodes, p. 17. Oxford University Press (1971).

5. Yu. V. Pleskov and V. Yu. Filinovskii, The Rotating-disc Electrode, Consultants Bureau, New York and London (1976).

6. F. T. B. J. van den Brink, thesis, Eindhoven (1981).

7. R. N. Adams, Electrochemistry at Solid Electrodes, p. 76. Marcel Dekker, New York (1969).

8. L. J. J. Janssen, unpublished results

9. S. Shibata, Electrochim. Acta 23, 619 (1978).

10. C. K. Bon and C. W. Tobias, J. electrochem. Soc. 115, $91 \mathrm{C}$ (1968).

11. E. A. Khomskaya and A. S. Kolossov, Sov. Elektrochem. 6. $245(1970)$ 